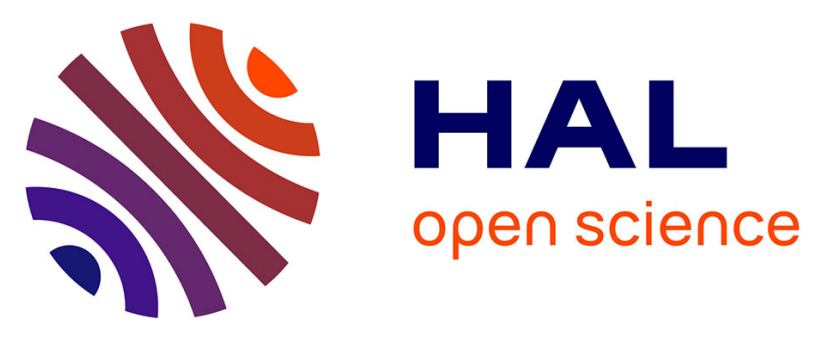

\title{
Predictive performance of blood S100B in the management of patients over 65 years old with mild traumatic brain injury
}

Charlotte Oris, Jean-Baptiste Bouillon-Minois, Jérémy Pinguet, Samy Kahouadji, Julie Durif, Vallauris Meslé, Bruno Pereira, Jeannot Schmidt, Vincent Sapin, Damien Bouvier

\section{To cite this version:}

Charlotte Oris, Jean-Baptiste Bouillon-Minois, Jérémy Pinguet, Samy Kahouadji, Julie Durif, et al.. Predictive performance of blood S100B in the management of patients over 65 years old with mild traumatic brain injury. Journals of Gerontology Series A: Biological Sciences and Medical Sciences, inPress, pp.glab055. 10.1093/gerona/glab055 . hal-03249807

\section{HAL Id: hal-03249807 https://hal.uca.fr/hal-03249807}

Submitted on 4 Jun 2021

HAL is a multi-disciplinary open access archive for the deposit and dissemination of scientific research documents, whether they are published or not. The documents may come from teaching and research institutions in France or abroad, or from public or private research centers.
L'archive ouverte pluridisciplinaire HAL, est destinée au dépôt et à la diffusion de documents scientifiques de niveau recherche, publiés ou non, émanant des établissements d'enseignement et de recherche français ou étrangers, des laboratoires publics ou privés. 
1 Title Predictive performance of blood S100B in the management of patients over 65 years old

2 with mild traumatic brain injury

3

4 Charlotte Oris ${ }^{1,2}$, PharmD; Jean-Baptiste Bouillon-Minois ${ }^{3}$, MD; Jérémy Pinguet ${ }^{1}$, engineer;

5 Samy Kahouadji ${ }^{1}$, PharmD; Julie Durif ${ }^{1}$, research assistant; Vallauris Meslé ${ }^{2}$, PharmD student;

6 Bruno Pereira ${ }^{4}, \mathrm{PhD}$; Jeannot $\mathrm{Schmidt}^{3}, \mathrm{MD}, \mathrm{PhD}$; Vincent Sapin ${ }^{1,2}$, PharmD, PhD; Damien

$7 \quad$ Bouvier $^{1,2}, \mathrm{MD}, \mathrm{PhD}$

$8{ }^{1}$ University Hospital, Biochemistry and Molecular Genetic Department, F-63000 Clermont9 Ferrand, France.

${ }^{2}$ Clermont Auvergne University, CNRS 6293, IINSERM 1103, GReD, F-63000 ClermontFerrand, France.

${ }^{3}$ University Hospital, Adult Emergency Department, F-63000 Clermont-Ferrand, France

${ }^{4}$ University Hospital, Biostatistics unit (DRCI) Department, F-63000 Clermont-Ferrand, France.

\section{Corresponding author}

Vincent Sapin

Service de Biochimie et Génétique Moléculaire, Centre de Biologie, CHU Gabriel Montpied 58 Rue Montalembert / 63000 Clermont-Ferrand, France

Phone: + 33473754882

vsapin@chu-clermontferrand.fr

Main text word count 4792 words

Number of data elements 3 tables, 2 figures, supplemental information (1 table, 1 figure) 
2 Background: We previously assessed the inclusion of S100B blood determination into clinical 3 decision rules for mild traumatic brain injury (mTBI) management in the Emergency 4 Department (ED) of Clermont-Ferrand Hospital. At the $0.10 \mu \mathrm{g} / \mathrm{L}$ threshold, S100B reduced 5 the use of cranial computed tomography (CCT) scan in adults by at least $30 \%$ with a $\sim 100 \%$ 6 sensitivity. Older patients had higher serum S100B values, resulting in lower specificity $7 \quad(18.7 \%)$ and decreased CCT reduction. We conducted this study to confirm the age effect on S100B concentrations, and to propose new decisional thresholds for older patients.

Methods: A total of 1172 mTBI patients aged 65 and over were included. They were divided into three age-groups: $65-79,80-89$, and $\geq 90$ years old. S100B's performance to identify intracranial lesions (sensitivity (SE) and specificity (SP)) was assessed using the routine 0.10 $\mu \mathrm{g} / \mathrm{L}$ threshold and also other more efficient thresholds established for each age group.

Results: S100B concentration medians were $0.18 \mu \mathrm{g} / \mathrm{L}, 0.26 \mu \mathrm{g} / \mathrm{L}$, and $0.32 \mu \mathrm{g} / \mathrm{L}$ for the 65 $79,80-89$, and $\geq 90$ years old age-groups, respectively $(\mathrm{p}<0.001)$. The most efficient thresholds were $0.11 \mu \mathrm{g} / \mathrm{L}$ for the $65-79$ age-group and $0.15 \mu \mathrm{g} / \mathrm{L}$ for the other groups. At these new thresholds, SP was respectively $28.4 \%, 34.3 \%$, and $20.5 \%$ for each age-group vs. $24.9 \%$, $18.2 \%$, and $10.5 \%$ at the $0.10 \mu \mathrm{g} / \mathrm{L}$ threshold.

Conclusions: Adjustment of the S100B threshold is necessary in older patients' management. An increased threshold of $0.15 \mu \mathrm{g} / \mathrm{L}$ is particularly interesting for patients $\geq 80$ years old, allowing a significant increase of CCT scan reduction (29.3\%).

\section{Keywords: biomarker, aging, dementia}




\section{INTRODUCTION}

Traumatic brain injury (TBI) constitutes a leading public health problem among older adults ( $>60$ years old) with an incidence of 275 per 100.000 in France (1). This is all the more important given the fact that the worldwide proportion of adults over 65 years old is expected to increase from $12.5 \%$ in 2010 to $20.0 \%$ by 2050 , reaching this proportion by 2030 in industrialized countries (2).

Although the spectrum of TBI severity is variable, $80 \%$ of treated TBIs are mild (3). Mild traumatic brain injury (mTBI), is defined by a Glasgow Coma Scale (GCS) of 13-15 (4), and according to clinical and anamnestic criteria, mTBI can be categorized into three prognostic subgroups: mTBI with a low, medium or high risk of complications $(5,6)$. The medium risk subgroup is particularly important as mTBI management guidelines recommend the use of cranial computed tomography (CCT) for this subgroup of patients although the vast majority $(85 \%-99 \%)$ of the CCTs performed don't find significant intracranial lesions (7). In this context, blood biomarkers can be used as a diagnostic tool for their ability to exclude intracranial lesions thus reducing the use of CCT scans.

S100B protein, is a well-established TBI biomarker. It is a small dimeric protein (molecular weight of $21 \mathrm{kDa}$ ) that consists of $\beta \beta$ or $\alpha \beta$ chains. S100B is commonly expressed in astrocytes and Schwann cells but also in melanocytes, chondrocytes, adipocytes and skeletal muscle (8). S100B is involved in a variety of intracellular and extracellular regulatory activities in central nervous system cells where it is highly expressed $(9,10)$. Increased blood S100B levels are associated with head trauma, in which damaged glial cells release S100B, it is then diffused into the bloodstream after passing through the blood-brain barrier (BBB). $\mathrm{S} 100 \mathrm{~B}$ is subsequently eliminated by the kidneys, with a short half-life of 30-100 minutes (11).

The usefulness of S100B in the management of mTBI has been established in many observational research and confirmed in two interventional studies $(12,13)$. The addition of 
1 blood S100B measurement to the Scandinavian guidelines decreased significantly the need for

2 CCT scans. It allowed a one-third reduction of the CCT scans performed in adult mTBI patients

3 (14). In a previous study, we validated the inclusion of S100B into our clinical decision rules

4 for mTBI management in a cohort of 1449 patients presenting to the Emergency Department

5 (ED) of Clermont-Ferrand's Hospital (15). In this study, at a threshold of $0.10 \mu \mathrm{g} / \mathrm{L}, \mathrm{S} 100 \mathrm{~B}$

6 reduced the use of CCT scans by $33.4 \%$ with a sensitivity of approximately $100 \%$. However,

7 older patients ( $>65$ years old), representing more than a third of the cohort, had higher serum

8 S100B values, resulting in a lower specificity of only $18.7 \%$ (15).

9 We conducted this study to evaluate in a larger cohort the effect of age on S100B 10 concentrations. The main outcome of this study is to propose new decisional thresholds $(\neq 0.10$

$11 \mu \mathrm{g} / \mathrm{L}$ ) adapted to older populations in order to improve S100B's specificity. 


\section{Study design and patients}

3 This study was carried out from June 2014 to March 2020 at the ED of Clermont-Ferrand

$4 \quad$ Hospital after approval by CPP Sud Est VI and in compliance with the Declaration of Helsinki

5 ethical principles regarding medical research involving human study participants. Patients were

6 informed of their right to express their disagreement regarding the use of their clinical

7 information for research purposes. Each patient referred to the ED for an mTBI (with a GCS $\geq$ 13) was classified into one of three prognostic subgroups according to the SFMU's recommendations (Société Française de Médecine d’Urgence) (5). The criteria regarding patients' categorization in the three subgroups and the clinical decision algorithm are presented in Figure 1.

The inclusion criteria were as follows: an age $\geq 65$ years old, an mTBI with medium risk of complications (i.e. with a GCS equal to 15 and antiplatelet treatment or loss of consciousness or retrograde amnesia 30 minutes before injury) and a time interval between injury and blood sampling being less than 3 hours (16).

The exclusion criteria were as follows: an age $<65$ years old, an mTBI with a low risk of complications (i.e. asymptomatic patient without medium- or high-risk criteria and a GCS of 15), an mTBI with a high risk of complications (Figure 1) and a time interval between injury and blood sampling being greater than 3 hours.

Concerning the clinical decision consecutive to S100B measurements: patients with S100B levels below the well-established decision threshold of $0.10 \mu \mathrm{g} / \mathrm{L}$ were categorized as having a low risk of complications and discharged (15). A CCT was strongly recommended within 8 hours for patients with S100B levels above the decision threshold (Figure 1).

For each patient who left the ED without a CCT, we checked if an hospitalization had occurred in the month following the mTBI. 


\section{Serum S100B measurement}

Serum S100B concentrations were determined by an electrochemiluminescence immunoassay using a Roche Diagnostics Cobas $\mathrm{e} 411^{\circledR}$ instrument (Meylan, France). S100B results were available within 1 hour after sampling. Based on other studies in adults, the cutoff was set at $0.10 \mu \mathrm{g} / \mathrm{L}$ (17-19). Patients exhibiting serum concentrations below this threshold were considered S100B negative (S100B-), and those with concentrations above this cutoff were considered S100B positive (S100B+).

According to the manufacturer's instructions, the test system requires $18 \mathrm{~min}$ and a probe volume of at least $120-\mu \mathrm{L}$ serum. The lower limit of quantification (LLOQ) and lower limit of detection (LLOD) are $0.02 \mu \mathrm{g} / \mathrm{L}$ and $0.005 \mu \mathrm{g} / \mathrm{L}$. Concentrations of up to $39 \mu \mathrm{g} / \mathrm{L}$ can be measured without dilution. The intra-assay and inter-assay coefficients of variation (CVs) are $<2.3 \%$ and $<5.6 \%$. The measurement uncertainty (calculated in the Biochemistry Department in Clermont-Ferrand, France) is $6 \%$ at a concentration of $0.183 \mu \mathrm{g} / \mathrm{L}$. This uncertainty must be taken into account when interpreting values close to the decision threshold $(0.10 \mu \mathrm{g} / \mathrm{L})$.

\section{Definition of Dementia}

In our study, patients suffering from dementia had one of the following neurological disorders: Alzheimer's disease, vascular dementia, Lewy body dementia, frontotemporal dementia and dementia of unknown etiology.

\section{CCT examination}

Each CCT scan was performed using a GE Healthcare Revolution GSI ${ }^{\circledR}$ according to the following protocol: a helical mode with a slice thickness of $2.25 \mathrm{~mm}$, interval of $1.25 \mathrm{~mm}, 120$ $\mathrm{kV}$ and a maximum of $280 \mathrm{~mA}$ from $\mathrm{C} 1$ to the top of the head with additional bone window reconstructions. To determine whether a patient had a trauma-relevant intracerebral lesion, the radiological parameters were recorded, and the patients were divided into two groups: one group with normal CCT scan for mTBI patients with no sign of trauma-relevant intracerebral 
1 lesion and another group with abnormal CCT scan for mTBI patients with at least one 2 pathophysiological trauma-relevant intracerebral lesion (such as petechiae, meningeal or 3 intraparenchymal effusion, pneumocephaly reflecting an osteomeningeal breach, compression 4 or ventricular hemorrhage).

5 


\section{Statistics}

All statistical analyses were performed using Stata software (Version 15, StataCorp, College Station, US) with a two-sided type I error at 5\%. Continuous data were presented as the median and minimum (min), maximum (max) and interquartile range (IQR). To study the relationship between S100B concentration and age, patients $(n=1172)$ were first, categorized into the following age-groups: $65-69,70-74,75-79,80-84,85-89,90-94, \geq 95$ years old. Then, they were divided into three age-groups according to statistical distribution and to two by two comparisons: $65-79,80-89$, and $\geq 90$ years old. The comparisons between age-groups concerning continuous parameters such as S100B concentrations were performed using ANOVA or Kruskal-Wallis tests. The assumption of normality was assessed by the ShapiroWilk test and the homoscedasticity was evaluated using Bartlett's test. When appropriate (omnibus p-value less than 0.05 ), post-hoc tests for multiple comparisons were applied: TukeyKramer after ANOVA and Dunn after Kruskal-Wallis. Sensitivity (SE), specificity (SP), positive predictive value (PPV) and negative predictive value (NPV) were estimated using the adult routine threshold of $0.10 \mu \mathrm{g} / \mathrm{L}$ for all patients and for each age-group. Then, based on the receiver operating characteristic (ROC) curve, the more efficient threshold (allowing the best SP keeping a 100\% SE) was evaluated for each age-group. For the 65-79 age-group, it was 0.11 $\mu \mathrm{g} / \mathrm{L}$ against $0.15 \mu \mathrm{g} / \mathrm{L}$ for the two other age-groups. The comparisons for paired proportions were performed using McNemar test whereas comparisons between groups for categorical data were carried out using Chi-squared or Fisher's exact tests. Multivariable analysis (linear for S100B as continuous variable and logistic for S100B according to threshold of $0.10 \mathrm{ug} / \mathrm{L}$ and optimal threshold) was conducted to take into account gender as confounder covariate. The residuals from these models was analyzed as aforementioned. When appropriate, a logarithmic transformation of dependent variable was applied. Sensitivity analyses were performed to 
1 ensure the robustness of the results and conclusions, performing aforementioned analyses on

2 patients without intracranial lesions $(n=1109)$ and patients without dementia $(n=893)$. 
$\underline{\text { RESULTS }}$

\section{Patient management and serum S100B concentration levels}

Between June 2014 and March 2020, serum S100B assays were performed for 1314 patients. A total of 1172 mTBI patients were enrolled in this study, 142 patients, meeting the exclusion criteria, were excluded (Figure 2). Of the 1172 patients, 504 were already included in our previous study (15). The median interval between brain injury and blood sampling was 1.6 hours (min: 0.2 hours, max: 3.0 hours, IQR: 1.3-2.1 hours). The median serum S100B level was $0.23 \mu \mathrm{g} / \mathrm{L}$ (min: $0.03 \mu \mathrm{g} / \mathrm{L}$; $\max : 8.97 \mu \mathrm{g} / \mathrm{L}$; IQR: $0.12-0.46 \mu \mathrm{g} / \mathrm{L}$ ). Of the 1172 patients included in the study, $954(81.4 \%)$ were S100B+ and $218(18.6 \%)$ were S100B- (Figure 2). Nevertheless, a CCT scan was performed for 67 S100B- patients, no abnormal scan was observed for these patients. Of the $954 \mathrm{~S} 100 \mathrm{~B}+$ patients, 60 were discharged without CCT scan, 831 had a normal CCT scan and 63 had an abnormal CCT scan (Figure 2). For 127 patients (10.8\%), the decision algorithm (Figure 2) was not followed by the physicians (CCT scan prescription despite S100B- or no prescription of CCT scan despite $\mathrm{S} 100 \mathrm{~B}+$ ) (Figure 2). Patients who left the ED without CCT scan did not develop any clinical signs suggestive of an intracerebral lesion in the month following mTBI. Moreover, we didn't find any hospitalization nor any death for these patients. Therefore, patients without CCT scans were considered as having no intracerebral lesions.

S100B levels according to age (Table 1)

For patients aged 65 to 80 , the median S100B concentration was $0.184 \mu \mathrm{g} / \mathrm{L}$ (min: $0.029 \mu \mathrm{g} / \mathrm{L}$; $\max : 7.74 \mu \mathrm{g} / \mathrm{L}$; IQR: $0.103-0.360 \mu \mathrm{g} / \mathrm{L}$ ). For patients aged 80 to 90 , the median $\mathrm{S} 100 \mathrm{~B}$ concentration was $0.255 \mu \mathrm{g} / \mathrm{L}$ (min: $0.032 \mu \mathrm{g} / \mathrm{L}$; max: $8.97 \mu \mathrm{g} / \mathrm{L}$; IQR: 0.129-0.474 $\mu \mathrm{g} / \mathrm{L}$ ). For patients aged 90 years and over, the median S100B concentration was $0.318 \mu \mathrm{g} / \mathrm{L}$ (min: 0.039 $\mu \mathrm{g} / \mathrm{L}$; max: $4.68 \mu \mathrm{g} / \mathrm{L}$; IQR: $0.178-0.609 \mu \mathrm{g} / \mathrm{L})$. S100B concentrations were significantly different between these three age-groups $(\mathrm{p}<0.001)$. 


\section{Population characteristics according to age (Table 2)}

For patients aged 65 to 80, median age was 73.5 years old (min: 65.0; max: 79.9; IQR: 69.476.9) and the sex ratio (M/F) was 1.1 . For patients aged 80 to 90 , median age was 85.1 years old (min: 80.0; $\max : 89.9$; IQR: 82.9-87.4) and the sex ratio (M/F) was 0.7. For patients aged 90 years and over, median age was 92.9 years old (min: 90.0; max: 105.1; IQR: 91.2-94.9) and the sex ratio $(\mathrm{M} / \mathrm{F})$ was 0.5 . The median time interval between $\mathrm{mTBI}$ and blood sample was not significantly different between the three age-groups $(\mathrm{p}=0.413)$. The proportions of S100B concentrations above the usual threshold of $0.10 \mu \mathrm{g} / \mathrm{L}$ were $76.1 \%, 82.9 \%$, and $90.2 \%$ for the three age-groups $(65-79,80-89$, and $\geq 90$ years old $)$, respectively $(\mathrm{p}<0.001)$. The proportion of positive CCT scans was not significantly different between the three age-groups $(p=0.11)$. Antiplatelet treatment was the most common risk factor: $n=272, n=386$, and $n=165$ for the three age-groups, respectively.

\section{S100B decisional threshold for older patients' management (Table 3)}

Of the 1172 patients included, $218(18.6 \%)$ had a negative S100B $(\leq 0.10 \mu \mathrm{g} / \mathrm{L})$. At the 0.10 $\mu \mathrm{g} / \mathrm{L}$ threshold, S100B identified intracranial lesions observed in CCT scans with a sensitivity of $100 \%$ (95\% CI: $94.3-100 \%)$, a specificity of $19.7 \%$ (95\%CI: $17.4-22.1 \%)$ and a negative predictive value of $100 \%$ (95\% CI: 98.3-100\%). For each age-group (65-79, 80-89, and $\geq 90$ years old), specificity was $24.9 \%$ (95\%CI: $21.0-29.1 \%), 18.2 \%$ (95\%CI: $14.8-22.1 \%)$, and 10.5\% (95\%CI: 6.6-15.8\%), respectively. A statistically significant difference was observed when comparing the specificities obtained for each age-group $(\mathrm{p}<0.001$ between patients aged 65 to 80 and patients aged 90 years and over, $p=0.02$ between patients aged 80 to 90 and patients aged 90 years and over, and $p=0.01$ between patients aged 65 to 80 and patients aged 80 to 90$)$.

Optimal S100B thresholds (allowing the best specificity while keeping a 100\% sensitivity) for each age group were determined and were as follows: $0.11 \mu \mathrm{g} / \mathrm{L}$ for patients aged 65 to 80 and 
$10.15 \mu \mathrm{g} / \mathrm{L}$ for the others. For patients aged 65 to 80 , the sensitivity was $100 \%$ (95\%CI: 81.5 -

$2100 \%$ ), the specificity was $28.4 \%$ (95\%CI: $24.3-32.8 \%$ ), and the negative predictive value was

$3100 \%$ (95\% CI: $97.2-100 \%)$. For patients aged 80 to 90 , the sensitivity was $100 \%(95 \% \mathrm{CI}$ :

88.4-100\%), the specificity was $34.3 \%$ (95\%CI: $29.9-38.8 \%$ ), and the negative predictive value was $100 \%(95 \%$ CI: $97.7-100 \%)$. For patients aged 90 years and over, the sensitivity was $100 \%$ (95\%CI: $78.2-100 \%$ ), the specificity was $20.5 \%$ (95\%CI: $15.0-27.0 \%$ ), and the negative predictive value was 100\% (95\% CI: 91.0-100\%). For each age-group, the specificity allowed by the optimal thresholds was significantly higher than the one observed with a $0.10 \mu \mathrm{g} / \mathrm{L}$ threshold (28.4\% vs $24.9 \%, 34.3 \%$ vs $18.2 \%$, and $20.5 \%$ vs $10.5 \%$; p $<0.001)$.

As the $0.15 \mu \mathrm{g} / \mathrm{L}$ threshold was common to both age-groups (80-89 and $\geq 90$ years old), performance was also assessed at this threshold for patients over the age of 80 . In these conditions, the sensitivity was $100 \%$ (95\% CI: $92.1-100 \%)$, the specificity was $29.3 \%$ (95\%CI: 25.9-33.0\%), and the negative predictive value was 100\% (95\% CI: 98.1-100\%). Furthermore, with the $0.15 \mu \mathrm{g} / \mathrm{L}$ threshold, the specificity for the $80-89$ age group (34.3\%) was significantly higher than the specificity for the $\geq 90$ years old age group $(20.5 \%),(p=0.001)$.

\section{Influence of Dementia (eTable 1)}

In our cohort, a total of 279 patients were suffering from dementia. The proportion of patients with dementia increased significantly with age: $11.3 \%$ for the age group $65-79,28.7 \%$ for the age group $80-89$, and $41.0 \%$ for the age group $\geq 90(p<0.001)$. Median S100B concentrations were significantly different when comparing patients with dementia $(0.301 \mu \mathrm{g} / \mathrm{L}$; min: 0.035 ; max: 8.97; IQR: 0.159-0.568) and others $(0.207 \mu \mathrm{g} / \mathrm{L}$; min: 0.029; $\max : 5.40$; IQR: $0.113-$ $0.415)(\mathrm{p}<0.001)$

The performance of the optimal thresholds was re-evaluated in patients without dementia $(\mathrm{n}=$ $893)$. For patients aged 65 to 80 , the specificity was $28.7 \%$ (95\%CI: $24.3-33.3 \%$ ) vs. $28.4 \%$ (95\%CI: $24.3-32.8 \%),(p=0.92)$. For patients aged 80 to 90 , the specificity was $37.5 \%(95 \% \mathrm{CI}$ : 
$132.2-42.9 \%)$ vs. $34.3 \%(95 \% \mathrm{CI}: 29.9-38.8 \%),(\mathrm{p}=0.36)$. For patients aged 90 years and over,

2 the specificity was $25.4 \%$ (95\%CI: $17.7-34.4 \%)$ vs. $20.5 \%(95 \% \mathrm{CI}: 15.0-27.0 \%),(\mathrm{p}=0.32)$.

3 The performance of the optimal thresholds was re-evaluated in patients with dementia $(\mathrm{n}=$

4279 ). For patients aged 65 to 80 , the specificity was $25.9 \%$ (95\%CI: $15.0-39.7 \%$ ) vs. $28.4 \%$

$5 \quad(95 \%$ CI: $24.3-32.8 \%),(p=0.70)$. For patients aged 80 to 90 , the specificity was $26.2 \%(95 \%$ CI:

$6 \quad 18.8-34.6 \%)$ vs. $34.3 \%(95 \%$ CI: $29.9-38.8 \%),(p=0.08)$. For patients aged 90 years and over,

7 the specificity was $13.2 \%(95 \% \mathrm{CI}: 6.5-22.9 \%)$ vs. $20.5 \%(95 \% \mathrm{CI}: 15.0-27.0 \%),(\mathrm{p}=0.16)$. 


\section{DISCUSSION}

The age effect on S100B blood concentrations was poorly investigated in previous studies. Children have higher levels of S100B concentrations than adults (20,21). However, S100B levels in older mTBI patients are less known. In 2013, Calgagnile et al. showed that S100B in older patients may be less effective regarding CCT scans reduction due to a very poor specificity (22). In a recent study including 504 mTBI patients over 65 years old, we established that these patients had higher serum S100B values than overall adult populations resulting in a low specificity of $18.7 \%$ (15). In order to study the age effect on S100B levels, we conducted this study on a larger cohort of 1172 older patients. The decision algorithm (Figure 1) was not applied by physicians for $127(10.8 \%)$ patients. This observation is similar to the $14 \%$ described by Calgagnile et al. (12). Our results confirm the low overall specificity (19.7\%). We also showed that S100B concentrations increase significantly with age. As expected, when using the routine $0.10 \mu \mathrm{g} / \mathrm{L}$ threshold, specificity is lower in older patients: $24.9 \%, 18.2 \%$, and $10.5 \%$ for the age-groups $65-79,80-89$, and $\geq 90$ years old, respectively. In order to regain specificity for older patients ( $\geq 65$ years old), we propose new decisional thresholds based on ROC curves analysis.

For patients aged 65 to 80 , a $0.11 \mu \mathrm{g} / \mathrm{L}$ threshold provides a $28.4 \%$ specificity instead of $24.9 \%$ with the $0.10 \mu \mathrm{g} / \mathrm{L}$ routine threshold. For patients aged 80 to 90 , specificity increases considerably with the new threshold of $0.15 \mu \mathrm{g} / \mathrm{L}$ (18.2\% to $34.3 \%)$, while sensitivity remains at $100 \%$. For patients aged 90 years and over, a $0.15 \mu \mathrm{g} / \mathrm{L}$ threshold enables a two-fold specificity increase (10.5\% to $20.5 \%)$ and a $100 \%$ sensitivity. Therefore, we propose the use of a $0.15 \mu \mathrm{g} / \mathrm{L}$ threshold for routine management of patients aged 80 years and over. This threshold $(0.15 \mu \mathrm{g} / \mathrm{L})$ is particularly interesting, allowing a $29.3 \%$ CCT scan reduction which is similar to the proportion in global adult population $(\sim 30 \%)(17-19)$. On the other hand, the threshold of $0.11 \mu \mathrm{g} / \mathrm{L}$ is less relevant for routine application due to the measurement uncertainty at this concentration level $(\sim 6 \%)$, which can lead to confusion with the $0.10 \mu \mathrm{g} / \mathrm{L}$ threshold. The 
determination of age related S100B clinical decision thresholds is consistent with recently published articles supporting the need for age-centered patients management (23). This is all the more important given the fact that older age is often included as a risk factor for complications consecutive to mTBI. In mTBI clinical decision rules, patients' age is the only demographic criterion used for risk stratification. Indeed, in most guidelines, patients aged over 65 years old are considered being at higher risk for having brain injury on CCT scan $(5,6,14)$.

The SFMU's recommendations consider amnesia or loss of consciousness as an intermediate risk factor if the symptom is associated with any of the following factors: dangerous mechanism of injury or patient's aged $\geq 65$ years old (5). Moreover, antiplatelet medication intake is also considered as an intermediate risk factor. Antiplatelet therapy is more common in older patients (24).

Sheng et al. showed that cortical expression of S100B increases with age (25). S100B levels measured in postmortem brain tissue of patients aged 60 years old and more without dementia, were higher than those observed in younger patients. However, all S100B levels remained below those seen in Alzheimer's patients (25). In Alzheimer's disease, S100B overexpression is explained by the role played by activated astrocytes in the pathogenesis of $\beta$-amyloid plaques (26). In mice, overexpression has been reported to exacerbate cerebral amyloidosis, which may be a vicious circle (27). Several hypotheses can be formulated in order to explain S100B blood increase with aging (eFigure 1). First of all, increasing levels of $\beta$-amyloid plaques in the brain may stimulate S100B synthesis as an attempt to regenerate neuronal damage $(28,29)$. It has been shown that S100B levels of older chronic schizophrenic patients are positively correlated with age and negatively with deficit symptoms. This suggests an impact of S100B in neuroplasticity and aging (28). Moreover, neuronal architecture is altered with increasing age while neuronal count does not change (30-33). A reduction in the complexity of dendrites arborization and dendritic length is observed, and spine numbers are also decreased $(33,34)$. As 
1 a result, astrocytes may be recruited for dendrites regrowth by releasing trophic factors

$2 \quad(31,35,36)$ like S100B protein. Neuroinflammation characteristic of aging ("inflammaging”) may also activate astrocytes cells $(35,37,38)$. Astrocyte reactivity may then lead to an exaggerated release of astrocytic biomarkers like $\operatorname{GFAP}(32,37)$ and potentially S100B. Astrocytes have a duality in their phenotype, neurotoxic or neuroprotective $(37,39)$. While astrocytes lose their neuroprotective functions in Alzheimer's disease (37), molecular changes upon physiological aging are more complex. During normal aging, the impact of astrocyte activation and reactive gliosis may be neuroprotective at first (39). Experimental data from selected central nervous system (CNS) pathologies suggest that if not resolved in time, reactive gliosis can exert inhibitory effects on neuroplasticity and CNS regeneration (39), which is consistent with S100B effects. Nanomolar concentrations of S100B exert neurotrophic effects by stimulating neurite outgrowth and regulating survival of neurons whereas micromolar concentrations are neurotoxic for the neuronal environment (40). Another hypothesis for the increased S100B blood levels observed in older adults is an increased BBB permeability. A meta-analysis reported a significant increase in BBB permeability in old healthy subjects $(\mathrm{n}=$ $238)$ when compared to younger healthy subjects $(n=213)(41)$. Increased S100B blood levels could also be linked to an extracerebral release since this protein is also expressed in other tissues such as skeletal muscle or bone tissue (8). A recent study showed an S100B increase in muscle cells in patients with sarcopenia (42). Another study showed higher S100B blood levels in patients with acute fractures without apparent cerebral injury $(43,44)$. A higher incidence of sarcopenia and fractures in older people could also explain the S100B increase in this population $(42,45)$. Furthermore, kidney function, which is known to decrease with age, may also contribute to the elevation of the S100B protein itself eliminated by the kidney $(46,47)$. However, Jönsson et al. showed that the elimination of S100B was not affected by a moderate reduction of glomerular filtration (48). This could be explained by the low molecular weight of 
S100B (21 kDa) allowing it to be easily filtered by the renal glomeruli. Lastly, in patients with end-stage renal disease, chronic inflammation and dysfunction of the BBB could increase the release of S100B by astrocytes and thus potentially explain the complication of cognitive impairment well known in these patients (49).

TBI results in astrocyte release of S100B, which may itself contribute to brain damage. Herrmann et al. showed, on a group of patients with mTBI, that increased posttraumatic concentrations of S100B help to identify the patients with a risk of long term neuropsychological dysfunction (50). In addition, S100B appears to be an important and useful predictor of functional outcome in moderate-to-severe TBI (51). An increase of S100B in traumatic brain conditions (micromolar levels) may contribute to brain damage by promoting inflammatory activities in astrocytes that cause neuronal dysfunction $(52,53)$. This observation is all the more relevant because older people have an exaggerated astrocytic reactivity with higher basal levels of S100B, which explains why post-traumatic concentrations more easily reach micromolar levels. Perhaps this is why the TBI can contribute to dementia (54). Aging also seems to alter the mechanisms of cerebral compensation, plasticity and cerebral reorganization of the brain (55). Moreover, older patients often have more difficulty making the required psychological adjustments to the traumatic event. Globally, S100B levels could in part explain the less favourable outcome for elderly patients (55).

Finally, we questioned the effect of Alzheimer's disease and other dementias on S100B concentrations. As expected, median S100B concentrations are significantly different between patients with dementia $(0.301 \mu \mathrm{g} / \mathrm{L})$ and others $(0.207 \mu \mathrm{g} / \mathrm{L})(\mathrm{p}<0.001)$. The high rate of dementia among patients over 90 years of age $(\sim 41.0 \%)$ in our study population is consistent with the estimated prevalence of dementia in France (56). In 2018, 40.8\% of people over 90 years old had dementia (56). In our cohort, the optimal threshold of $0.15 \mu \mathrm{g} / \mathrm{L}$ would have avoided $20 \%$ of CCT-scans in people over 90 years old against $10 \%$ with the routine threshold 
of $0.10 \mu \mathrm{g} / \mathrm{L}$. The exclusion of patients with dementia could enable a $25 \%$ CCT scans reduction instead of $20 \%$ when these were included. Although there is no statistically significant difference between the two values $(\mathrm{p}=0.32)$, a $25 \%$ specificity is closer to the one in average adult populations $(\sim 30 \%)$ and the AUC for this subgroup is not significant. In addition, we obtain lower specificity values in dementia patients compared to our whole cohort. For patients aged 90 years and over, the specificity falls from $20 \%$ to $13 \%$. Once again, the difference is not significant $(p=0.16)$, which proves the necessity for a new study focused on dementia patients to revaluate optimal thresholds.

Recently, similar studies in older patients have also shown a reduced specificity of serum Glial Fibrillary Acidic Protein (GFAP) $(23,57)$ and Ubiquitin Carboxy-terminal Hydrolase L1 (UCHL1) (23). Only Tau protein has been shown to have equivalent specificity performance between different age-groups (57). Another study, presenting data on GFAP and Neurofilament Light (NFL) levels in the cerebrospinal fluid of healthy participants, showed an increase in both biomarkers with increasing age (58). Finally, these data point to the influence of older age on candidate mTBI biomarkers. As for S100B, thresholds' adjustment will be necessary in older patients' management. Due to the retrospective nature of the study, we were unable to measure any brain biomarkers other than S100B. These assays will be the subject of future work.

\section{One of the limitations of the study was the lack of direct ascertainment of intracranial lesions}

in some patients. Moreover, clinical data on dementia was collected retrospectively, and the etiology of dementia could not be identified for all patients. Some information (such as the time between the trauma and the blood sample) provided by patients with dementia may be questionable. In addition, future work will be required to achieve a better pathophysiological understanding of blood S100B increase in older patients. Finally, the retrospective nature of the study limited us in collecting data such as co-morbid conditions (e.g. chronic kidney disease, 
1 estimated glomerular filtration rate (eGFR) reduction, sarcopenia, recent bone fractures) or

2 medication intake (glucocorticoids, other anti-inflammatory drugs, ...).

3 In conclusion, S100B levels are considerably affected by age. At the routine threshold $(0.10$

$4 \mu \mathrm{g} / \mathrm{L})$, its clinical utility is very limited by a poor specificity leading to only a small decrease in

5 CCT scanning. Adjustment of the S100B threshold is necessary in older patients' management.

6 An optimal $0.15 \mu \mathrm{g} / \mathrm{L}$ threshold is particularly interesting for patients over 80 years of age with

$7 \mathrm{a} \sim 30 \% \mathrm{CCT}$ scans reduction, which is comparable to the CCT scans reduction allowed in 8 relatively younger adults. To validate the accuracy of our results, a future prospective study will

9 be needed.

\section{Conflict of Interest}

11 The authors have no conflicts.

\section{Funding}

13 The authors have no funding disclosures. 
2 1. Popescu C, Anghelescu A, Daia C, Onose G. Actual data on epidemiological evolution 3 and prevention endeavours regarding traumatic brain injury. J Med Life. 2015;8(3):272-7.

4 2. Vincent GK, Velkov AV. The Next Four Decades, The Older Population in the United

5 States: 2010 to 2050. U.S. Department of Commerce, Economics and Statistics Administration,

$6 \quad$ U.S. Census Bureau, 2010, pp 25-1138.

7 3. Bazarian JJ, Mcclung J, Shah MN, Ting Cheng Y, Flesher W, Kraus J. Mild traumatic 8 brain injury in the United States, 1998-2000. Brain Inj. 2005;19(2):85-91. 9 doi:10.1080/02699050410001720158.

4. Tazarourte K, Macaine C, Didane H, Dékadjevi H. [Traumatisme crânien non grave]. EMC - Médecine Urgence. Elsevier Masson, 2007. doi: 10.1016/S0000-0000(07)07659-0. 5. Comité de pilotage, Jehlé E, Honnart D, et al. [Traumatisme crânien léger (score de Glasgow de 13 à 15) : triage, évaluation, examens complémentaires et prise en charge précoce chez le nouveau-né, l'enfant et l'adulte]. Ann Fr Médecine Urgence. 2012;2(3):199-214. doi:10.1007/s13341-012-0202-4.

6. Stiell IG, Wells GA, Vandemheen K, et al. The Canadian CT Head Rule for patients with minor head injury. The Lancet. 2001;357(9266):1391-1396. doi:10.1016/S01406736(00)04561-X.

7. Haydel MJ, Blaudeau E. Indications for Computed Tomography in Patients with Minor Head Injury. N Engl J Med. 2000; 343:100-105.

8. Donato R, Heizmann CW. S100B Protein in the Nervous System and Cardiovascular Apparatus in Normal and Pathological Conditions. Cardiovasc Psychiatry Neurol. 2010;2010:1-2. doi:10.1155/2010/929712 
1 9. Zimmer DB, Cornwall EH, Landar A, Song W. The S100 protein family: history,

2 function, and expression. Brain Res Bull. 1995;37(4):417-429.

3 10. Donato R, Isobe T, Okuyama T. S-100 proteins and microtubules: analysis of the effects

4 of rat brain S-100 (S-100b) and ox brain S-100a0, S-100a and S-100b on microtubule assembly-

5 disassembly. FEBS Lett. 1985;186(1):65-69.

6 11. Townend W, Dibble C, Abid K, Vail A, Sherwood R, Lecky F. Rapid elimination of

7 protein S-100B from serum after minor head trauma. J Neurotrauma. 2006;23(2):149-155.

8 doi:10.1089/neu.2006.23.149.

9 12. Calcagnile O, Undén L, Undén J. Clinical validation of S100B use in management of mild head injury. BMC Emerg Med. 2012;12(1):13. doi:10.1186/1471-227X-12-13.

13. Undén L, Calcagnile $\mathrm{O}$, Undén $\mathrm{J}$, Reinstrup $\mathrm{P}$, Bazarian J. Validation of the

Scandinavian guidelines for initial management of minimal, mild and moderate traumatic brain injury in adults. BMC Med. 2015;13(1):292. doi:10.1186/s12916-015-0533-y.

14. The Scandinavian Neurotrauma Committee (SNC), Undén J, Ingebrigtsen T, Romner

B. Scandinavian guidelines for initial management of minimal, mild and moderate head injuries in adults: an evidence and consensus-based update. BMC Med. 2013;11(1):50. doi:10.1186/1741-7015-11-50.

15. Allouchery G, Moustafa F, Roubin J, et al. Clinical validation of S100B in the management of a mild traumatic brain injury: issues from an interventional cohort of 1449 adult patients. Clin Chem Lab Med CCLM. 2018;56(11):1897-1904. doi:10.1515/cclm-2018-0471.

16. Laribi S, Kansao J, Borderie D, et al. S100B blood level measurement to exclude cerebral lesions after minor head injury: the multicenter STIC-S100 French study. Clin Chem 
1 17. Biberthaler P, Linsenmeier U, Pfeifer K-J, et al. Serum S-100B concentration provides

2 additional information for the indication of computed tomography in patients after minor head

3 injury: a prospective multicenter study. Shock. 2006;25(5):446-453.

4 doi:10.1097/01.shk.0000209534.61058.35.

5 18. Bouvier D, Oddoze C, Ben Haim D, et al. [Interest of S100B protein blood level

6 determination for the management of patients with minor head trauma]. Ann Biol Clin.

$7 \quad$ 2009;67(4):425-431. doi:10.1684/abc.2009.0347.

8 19. Unden J, Romner B. Can Low Serum Levels of S100B Predict Normal CT Findings 9 After Minor Head Injury in Adults?: An Evidence-Based Review and Meta-Analysis. J Head Trauma Rehabil. 2010;25(4):228-40. doi: 10.1097/HTR.0b013e3181e57e22.

20. Bouvier D, Fournier M, Dauphin J-B, et al. Serum S100B Determination in the Management of Pediatric Mild Traumatic Brain Injury. Clin Chem. 2012;58(7):1116-1122. doi:10.1373/clinchem.2011.180828.

21. Oris C, Pereira B, Durif J, et al. The Biomarker S100B and Mild Traumatic Brain Injury: A Meta-analysis. Pediatrics. 2018;141(6):e20180037. doi:10.1542/peds.2018-0037.

22. Calcagnile O, Holmén A, Chew M, Undén J. S100B levels are affected by older age but not by alcohol intoxication following mild traumatic brain injury. Scand J Trauma Resusc Emerg Med. 2013;21(1):52. doi:10.1186/1757-7241-21-52

23. Ward MD, Weber A, Merrill VD, Welch RD, Bazarian JJ, Christenson RH. Predictive performance of traumatic brain injury biomarkers in high-risk elderly patients. J Appl Lab Med. 2020 May 1;5(3):608. 
1 24. Williams CD, Chan AT, Elman MR, et al. Aspirin Use Among Adults in the U.S. Am J

2 Prev Med. 2015;48(5):501-508. doi:10.1016/j.amepre.2014.11.005

3 25. Sheng JG, Mrak E, Rovnaghi R, Eldik LJV. Human Brain S10013 and S10013 mRNA

4 Expression Increases With Age: Pathogenic Implications for Alzheimer's Disease. Neurobiol $5 \quad$ Aging. 1996;17(3):359-63. doi: 10.1016/0197-4580(96)00037-1.

6 26. Mrak R. The role of activated astrocytes and of the neurotrophic cytokine S100B in the

7 pathogenesis of Alzheimer's disease. Neurobiol Aging. 2001;22(6):915-922. 8 doi:10.1016/S0197-4580(01)00293-7.

9 27. Mori T, Koyama N, Arendash GW, Horikoshi-Sakuraba Y, Tan J, Town T. Overexpression of human S100B exacerbates cerebral amyloidosis and gliosis in the $\operatorname{Tg} 2576$ mouse model of Alzheimer's disease. Glia. 2010;58(3):300-14. doi:10.1002/glia.20924.

28. Schmitt A, Bertsch T, Henning U, et al. Increased serum S100B in elderly, chronic schizophrenic patients: Negative correlation with deficit symptoms. Schizophr Res. 2005;80(23):305-313. doi:10.1016/j.schres.2005.04.013

29. Pena LA, Brecher CW, Marshak DR. 13-Amyloid regulates gene expression of glial trophic substance S100/3 in C6 glioma and primary astrocyte cultures. Brain Res Mol Brain Res. 1995 Dec 1;34(1):118-26. doi: 10.1016/0169-328x(95)00145-i.

30. Freeman SH, Kandel R, Cruz L, et al. Preservation of Neuronal Number Despite AgeRelated Cortical Brain Atrophy in Elderly Subjects Without Alzheimer Disease. J Neuropathol Exp Neurol. 2008;67(12):1205-1212. doi:10.1097/NEN.0b013e31818fc72f. 
1 31. Agid Y. [Vieillissement cérébral ou maladie dégénérative]. Colloque Chimie et cerveau,

2 2014, pp 76-86. https://www.mediachimie.org/ressource/vieillissement-cerebral-ou-maladie3 degenerative.

4 32. Palmer AL, Ousman SS. Astrocytes and Aging. Front Aging Neurosci. 2018;10:337. 5 doi:10.3389/fnagi.2018.00337.

6 33. Dickstein DL, Kabaso D, Rocher AB, Luebke JI, Wearne SL, Hof PR. Changes in the 7 structural complexity of the aged brain. Aging Cell. 2007;6(3):275-284. doi:10.1111/j.1474$8 \quad 9726.2007 .00289 . x$.

9 34. Benavides-Piccione R, Fernaud-Espinosa I, Robles V, Yuste R, DeFelipe J. Age-Based Comparison of Human Dendritic Spine Structure Using Complete Three-Dimensional Reconstructions. Cereb Cortex. 2013;23(8):1798-1810. doi:10.1093/cercor/bhs154.

35. Rodríguez-Arellano JJ, Parpura V, Zorec R, Verkhratsky A. Astrocytes in physiological aging and and Alzheimer' disease. $\quad$ Neuroscience. 2016;323:170-182. doi:10.1016/j.neuroscience.2015.01.007. 36. Coleman PD, Flood DG. Dendritic proliferation in the aging brain as a compensatory repair mechanism. Elsevier, 1986, pp 227-237. doi:10.1016/S0079-6123(08)64307-1. Disease. Front Aging Neurosci. 2019;11:59. doi:10.3389/fnagi.2019.00059. 38. Taipa R, Ferreira V, Brochado P, et al. Inflammatory pathology markers (activated microglia and reactive astrocytes) in early and late onset Alzheimer disease: a post mortem study. Neuropathol Appl Neurobiol. 2018;44(3):298-313. doi:10.1111/nan.12445. 
1 39. Pekny M, Wilhelmsson U, Pekna M. The dual role of astrocyte activation and reactive

2 gliosis. Neurosci Lett. 2014;565:30-38. doi:10.1016/j.neulet.2013.12.071.

3 40. Huttunen HJ, Kuja-Panula J, Sorci G, Agneletti AL, Donato R, Rauvala H. Coregulation

4 of Neurite Outgrowth and Cell Survival by Amphoterin and S100 Proteins through Receptor

5 for Advanced Glycation End Products (RAGE) Activation. J Biol Chem. 2000;275(51):40096-

$6 \quad$ 40105. doi:10.1074/jbc.M006993200.

7 41. Farrall AJ, Wardlaw JM. Blood-brain barrier: Ageing and microvascular disease -

8 systematic review and meta-analysis. Neurobiol Aging. 2009;30(3):337-352.

9 doi:10.1016/j.neurobiolaging.2007.07.015.

42. Riuzzi F, Sorci G, Arcuri C, et al. Cellular and molecular mechanisms of sarcopenia: the S100B perspective: S100B and sarcopenia. J Cachexia Sarcopenia Muscle. 2018;9(7):12551268. doi:10.1002/jcsm. 12363.

43. Unden J, Bellner J, Eneroth M, Alling C, Ingebrigtsen T, Romner B. Raised Serum S100B Levels after Acute Bone Fractures without Cerebral Injury: J Trauma Inj Infect Crit Care. 2005;58(1):59-61. doi:10.1097/01.TA.0000130613.35877.75.

44. Kahouadji S, Salamin P, Praz L, et al. S100B Blood Level Determination for Early Management of Ski-Related Mild Traumatic Brain Injury: A Pilot Study. Front Neurol. 2020;11:856. doi:10.3389/fneur.2020.00856.

45. Singer BR, McLauchlan GJ, Robinson CM, Christie J. Epidemiology of fractures in 15 000 adults: The influence of age and gender. J Bone Joint Surg Br. 1998;80-B(2):243-248. doi:10.1302/0301-620X.80B2.0800243. 
1 46. Li JP, Lu L, Wang LJ, Zhang FR, Shen WF. Increased serum levels of S100B are related

2 to the severity of cardiac dysfunction, renal insufficiency and major cardiac events in patients

3 with chronic heart failure. Clin Biochem. 2011;44(12):984-988.

4 doi:10.1016/j.clinbiochem.2011.05.014.

5 47. Gross S, Homan van der Heide JJJ, van Son WJ, Gans ROB, et al. Body mass index and

6 creatinine clearance are associated with steady-state serum concentrations of the cell damage

7 marker S100B in renal transplant recipients. Med Sci Monit. 2010 Jul;16(7):CR318-24.

8 48. Jönsson H, Johnsson P, Höglund P, Alling C, Blomquist S. Elimination of S100B and

9 renal function after cardiac surgery. J Cardiothorac Vasc Anesth. 2000;14(6):698-701. doi:10.1053/jcan.2000.18444.

49. Park BS, Lee HW, Lee YJ, et al. Serum S100B represents a biomarker for cognitive impairment in patients with end-stage renal disease. Clin Neurol Neurosurg. 2020;195:105902. doi:10.1016/j.clineuro.2020.105902.

50. Herrmann M. Release of biochemical markers of damage to neuronal and glial brain tissue is associated with short and long term neuropsychological outcome after traumatic brain injury. J Neurol Neurosurg Psychiatry. 2001;70(1):95-100. doi:10.1136/jnnp.70.1.95.

51. Thelin EP, Nelson DW, Bellander B-M. A review of the clinical utility of serum S100B protein levels in the assessment of traumatic brain injury. Acta Neurochir (Wien). 2017;159(2):209-225. doi:10.1007/s00701-016-3046-3.

52. Arolt V, Peters M, Erfurth A, et al. S100B and response to treatment in major depression: a pilot study. Eur Neuropsychopharmacol. 2003;13(4):235-239. doi:10.1016/S0924-977X(03)00016-6. 
1 53. Donato R. RAGE: A Single Receptor for Several Ligands and Different Cellular

2 Responses: The Case of Certain S100 Proteins. Curr Mol Med. 2007;7(8):711-724. 3 doi:10.2174/156652407783220688.

4 54. Gardner RC, Burke JF, Nettiksimmons J, Kaup A, Barnes DE, Yaffe K. Dementia Risk 5 After Traumatic Brain Injury vs Nonbrain Trauma: The Role of Age and Severity. JAMA $6 \quad$ Neurol. 2014;71(12):1490. doi:10.1001/jamaneurol.2014.2668.

7 55. LeBlanc J, Guise E de, Gosselin N, Feyz M. Comparison of functional outcome 8 following acute care in young, middle-aged and elderly patients with traumatic brain injury. Brain Inj. 2006;20(8):779-790. doi:10.1080/02699050600831835.

56. Estimating the prevalence of dementia in Europe. The 2019 Alzheimer Europe Yearbook. https://www.alzheimer-europe.org/Publications/Dementia-in-Europe-Yearbooks.

57. Gardner RC, Rubenstein R, Wang KKW, et al. Age-Related Differences in Diagnostic Accuracy of Plasma Glial Fibrillary Acidic Protein and Tau for Identifying Acute Intracranial Trauma on Computed Tomography: A TRACK-TBI Study. J Neurotrauma. 2018;35(20):23412350. doi:10.1089/neu.2018.5694.

58. Vågberg M, Norgren N, Dring A, et al. Levels and Age Dependency of Neurofilament Light and Glial Fibrillary Acidic Protein in Healthy Individuals and Their Relation to the Brain Parenchymal Fraction. PLoS One. 2015;10(8):e0135886. doi: 10.1371/journal.pone.0135886. 


\section{TABLE LEGENDS}

2 Table 1: S100B concentration levels according to age.

3 IQR: interquartile range; max: maximum; min: minimum. These data include the entire 4 population (CCT performed or not) $(\mathrm{n}=1172)$.

5 Table 2: Population characteristics according to age.

6 AT : antiplatelet treatment; CCT: cranial computed tomography; CCT+: $\geq 1$ intracerebral

7 lesion; F: females; h: hours; IQR: interquartile range; LC: loss of consciousness; M: males;

8 max: maximum; min: minimum; RA: retrograde amnesia; $\uparrow$ : time between trauma and sample;

$9 *$ : $p$ value of a multivariate model including gender.

Table 3: Analysis of sensitivity (SE), specificity (SP), positive predictive value (PPV) and negative predictive value (NPV) for the two thresholds tested on the three age categories. AUC: area under ROC curve; yo: years old; *: Optimal threshold (keeping 100\% SE): 0.11 $\mu \mathrm{g} / \mathrm{L}$ for patients aged 65 to $80,0.15 \mu \mathrm{g} / \mathrm{L}$ for patients aged 80 to 90 , and $0.15 \mu \mathrm{g} / \mathrm{L}$ for patients aged 90 years and over; $\uparrow:$ Comparison of the specificity obtained at the $0.10 \mu \mathrm{g} / \mathrm{L}$ threshold to that obtained at the optimal threshold. 
1 Table 1: S100B concentration levels according to age

2

\begin{tabular}{|c|c|c|c|c|}
\hline Age-group & $\mathbf{n}$ & \multicolumn{2}{|c|}{ S100B median, $\mu \mathrm{g} / \mathrm{L}(\min ; \max ; \mathrm{IQR})$} & $p$ value \\
\hline 65-69 & 138 & $\begin{array}{c}0.183 \\
(0.032 ; 4.18 ; 0.090-0.381)\end{array}$ & & \\
\hline 70-74 & 160 & $\begin{array}{c}0.187 \\
(0.038 ; 3.77 ; 0.105-0.360)\end{array}$ & $\begin{array}{c}0.184 \\
(0.029 ; 7.74 ; 0.103-0.360)\end{array}$ & \\
\hline 75-79 & 178 & $\begin{array}{c}0.182 \\
(0.029 ; 7.74 ; 0.109-0.343)\end{array}$ & & \\
\hline 80-84 & 239 & $\begin{array}{c}0.235 \\
(0.035 ; 5.40 ; 0.129-0.468)\end{array}$ & 0.255 & $<0.001$ \\
\hline 85-89 & 252 & $\begin{array}{c}0.266 \\
(0.032 ; 8.97 ; 0.128-0.486)\end{array}$ & $(0.032 ; 8.97 ; 0.129-0.474)$ & \\
\hline 90-94 & 154 & $\begin{array}{c}0.317 \\
(0.039 ; 3.52 ; 0.168-0.608)\end{array}$ & 0.318 & \\
\hline$\geq 95$ & 51 & $\begin{array}{c}0.331 \\
(0.086 ; 4.68 ; 0.179-0.700)\end{array}$ & $(0.039 ; 4.68 ; 0.178-0.609)$ & \\
\hline
\end{tabular}

3

4 IQR: interquartile range; max: maximum; min: minimum.

5 These data include the entire population (CCT performed or not) $(\mathrm{n}=1172)$. 
1 Table 2: Population characteristics according to age

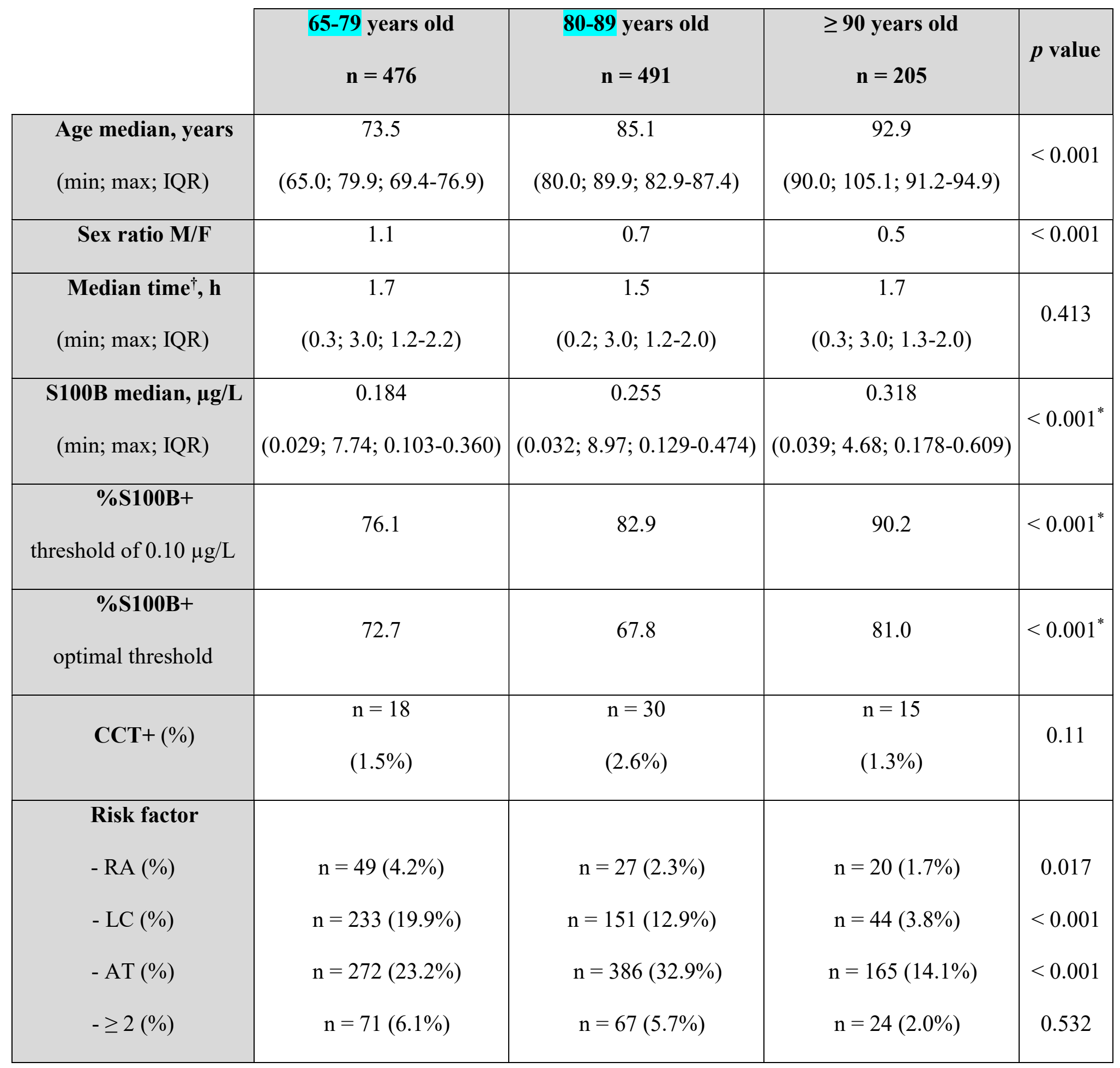

2 AT : antiplatelet treatment; CCT: cranial computed tomography; $\mathrm{CCT}+: \geq 1$ intracerebral

3 lesion; F: females; h: hours; IQR: interquartile range; LC: loss of consciousness; M: males;

4 max: maximum; min: minimum; RA: retrograde amnesia; $\uparrow$ : time between trauma and sample;

$5 \quad *$ : $p$ value of a multivariate model including gender. 
1 Table 3: Analysis of sensitivity (SE), specificity (SP), positive predictive value (PPV) and negative predictive value (NPV) for the two thresholds

2 tested on the three age categories.

\begin{tabular}{|c|c|c|c|c|c|c|c|c|c|c|}
\hline & \multirow{2}{*}{$\begin{array}{c}\text { AUC } \\
(95 \% \mathrm{CI})\end{array}$} & \multicolumn{4}{|c|}{ Threshold of $0.10 \mu \mathrm{g} / \mathrm{L}$} & \multicolumn{4}{|c|}{ Optimal threshold* } & \multirow[b]{2}{*}{$p$ value $^{\dagger}$} \\
\hline & & $\begin{array}{c}\text { SE } \\
(95 \% \mathrm{CI})\end{array}$ & $\begin{array}{c}\text { SP } \\
(95 \% \mathrm{CI})\end{array}$ & $\begin{array}{c}\text { PPV } \\
(95 \% \mathrm{CI})\end{array}$ & $\begin{array}{c}\text { NPV } \\
(95 \% \mathrm{CI})\end{array}$ & $\begin{array}{c}\text { SE } \\
(95 \% \mathrm{CI})\end{array}$ & $\begin{array}{c}\text { SP } \\
(95 \% \mathrm{CI})\end{array}$ & $\begin{array}{c}\text { PPV } \\
(95 \% \mathrm{CI})\end{array}$ & $\begin{array}{c}\text { NPV } \\
(95 \% \mathrm{CI})\end{array}$ & \\
\hline All patients & $\begin{array}{c}0.71 \\
(0.66-0.76)\end{array}$ & $\begin{array}{c}100 \\
(94.3-100)\end{array}$ & $\begin{array}{c}19.7 \\
(17.4-22.1)\end{array}$ & $\begin{array}{c}6.6 \\
(5.1-8.4)\end{array}$ & $\begin{array}{c}100 \\
(98.3-100)\end{array}$ & / & / & / & / & / \\
\hline 65-79 yo & $\begin{array}{c}0.71 \\
(0.61-0.82)\end{array}$ & $\begin{array}{c}100 \\
(81.5-100)\end{array}$ & $\begin{array}{c}\mathbf{2 4 . 9} \\
(21.0-29.1)\end{array}$ & $\begin{array}{c}5.0 \\
(3.0-7.7)\end{array}$ & $\begin{array}{c}100 \\
(96.8-100)\end{array}$ & $\begin{array}{c}100 \\
(81.5-100)\end{array}$ & $\begin{array}{c}\mathbf{2 8 . 4} \\
(24.3-32.8)\end{array}$ & $\begin{array}{c}5.2 \\
(3.1-8.1)\end{array}$ & $\begin{array}{c}100 \\
(97.2-100)\end{array}$ & $<0.001$ \\
\hline 80-89 yo & $\begin{array}{c}0.75 \\
(0.68-0.82)\end{array}$ & $\begin{array}{c}100 \\
(88.4-100)\end{array}$ & $\begin{array}{c}18.2 \\
(14.8-22.1)\end{array}$ & $\begin{array}{c}7.4 \\
(5.0-10.4)\end{array}$ & $\begin{array}{c}100 \\
(95.7-100)\end{array}$ & $\begin{array}{c}100 \\
(88.4-100)\end{array}$ & $\begin{array}{c}\mathbf{3 4 . 3} \\
(29.9-38.8)\end{array}$ & $\begin{array}{c}9.0 \\
(6.2-12.6)\end{array}$ & $\begin{array}{c}100 \\
(97.7-100)\end{array}$ & $<0.001$ \\
\hline$\geq 90$ yo & $\begin{array}{c}0.55 \\
(0.45-0.65)\end{array}$ & $\begin{array}{c}100 \\
(78.2-100)\end{array}$ & $\begin{array}{c}10.5 \\
(6.6-15.8)\end{array}$ & $\begin{array}{c}8.1 \\
(4.6-13.0)\end{array}$ & $\begin{array}{c}100 \\
(83.2-100)\end{array}$ & $\begin{array}{c}100 \\
(78.2-100)\end{array}$ & $\begin{array}{c}\mathbf{2 0 . 5} \\
(15.0-27.0)\end{array}$ & $\begin{array}{c}9.0 \\
(5.2-14.5)\end{array}$ & $\begin{array}{c}100 \\
(91.0-100)\end{array}$ & $<0.001$ \\
\hline
\end{tabular}

3 AUC: area under ROC curve; yo: years old; *: Optimal threshold (keeping 100\% SE): $0.11 \mu \mathrm{g} / \mathrm{L}$ for patients aged 65 to $80,0.15 \mu \mathrm{g} / \mathrm{L}$ for patients

4 aged 80 to 90 , and $0.15 \mu \mathrm{g} / \mathrm{L}$ for patients aged 90 years and over; $\dagger:$ Comparison of the specificity obtained at the $0.10 \mu \mathrm{g} / \mathrm{L}$ threshold to that

5 obtained at the optimal threshold. 


\section{FIGURE LEGENDS}

2 Figure 1: Decision algorithm for patients' management with mild traumatic brain injury

3 (mTBI) at the Clermont-Ferrand Emergency Department. The reference threshold is $4 \quad$ internationally defined as $0.10 \mu \mathrm{g} / \mathrm{L}$ for adults.

5 CCT: Cranial Computed Tomography; GCS: Glasgow Coma Scale; h: hours; LOC: Loss Of 6 Consciousness.

7 Figure 2: Flow chart of patients included, S100B protein results and CCT results.

8 CCT: Cranial Computed Tomography; GCS: Glasgow Coma Scale; mTBI: mild Traumatic

9 Brain Injury; S100B-: serum concentrations below the cutoff $(<0.10 \mu \mathrm{g} / \mathrm{L})$; S100+: serum concentrations above the cutoff $(\geq 0.10 \mu \mathrm{g} / \mathrm{L})$; ø CCT: CCT not performed. 


\section{Figure 1}

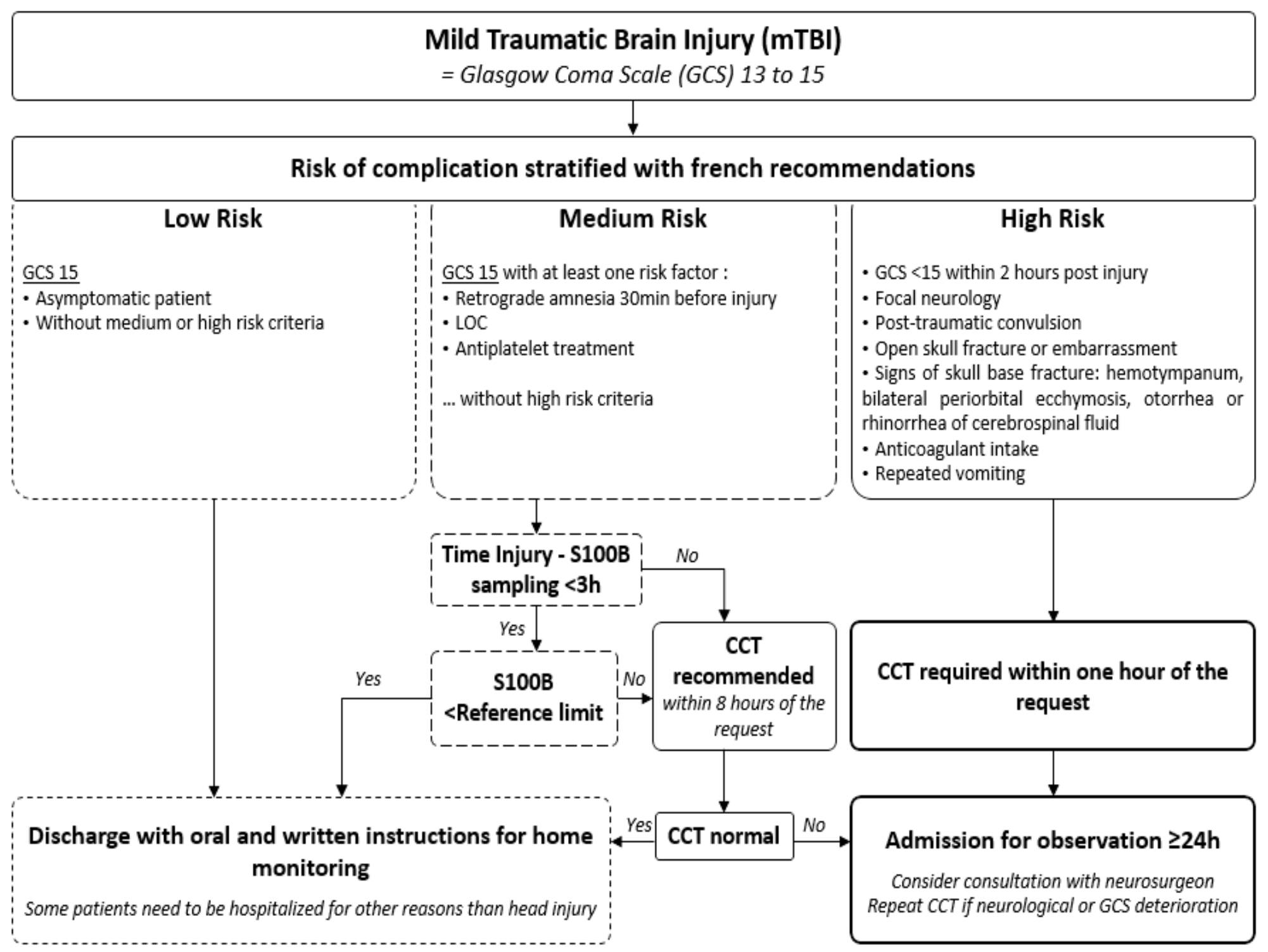




\section{Figure 2}

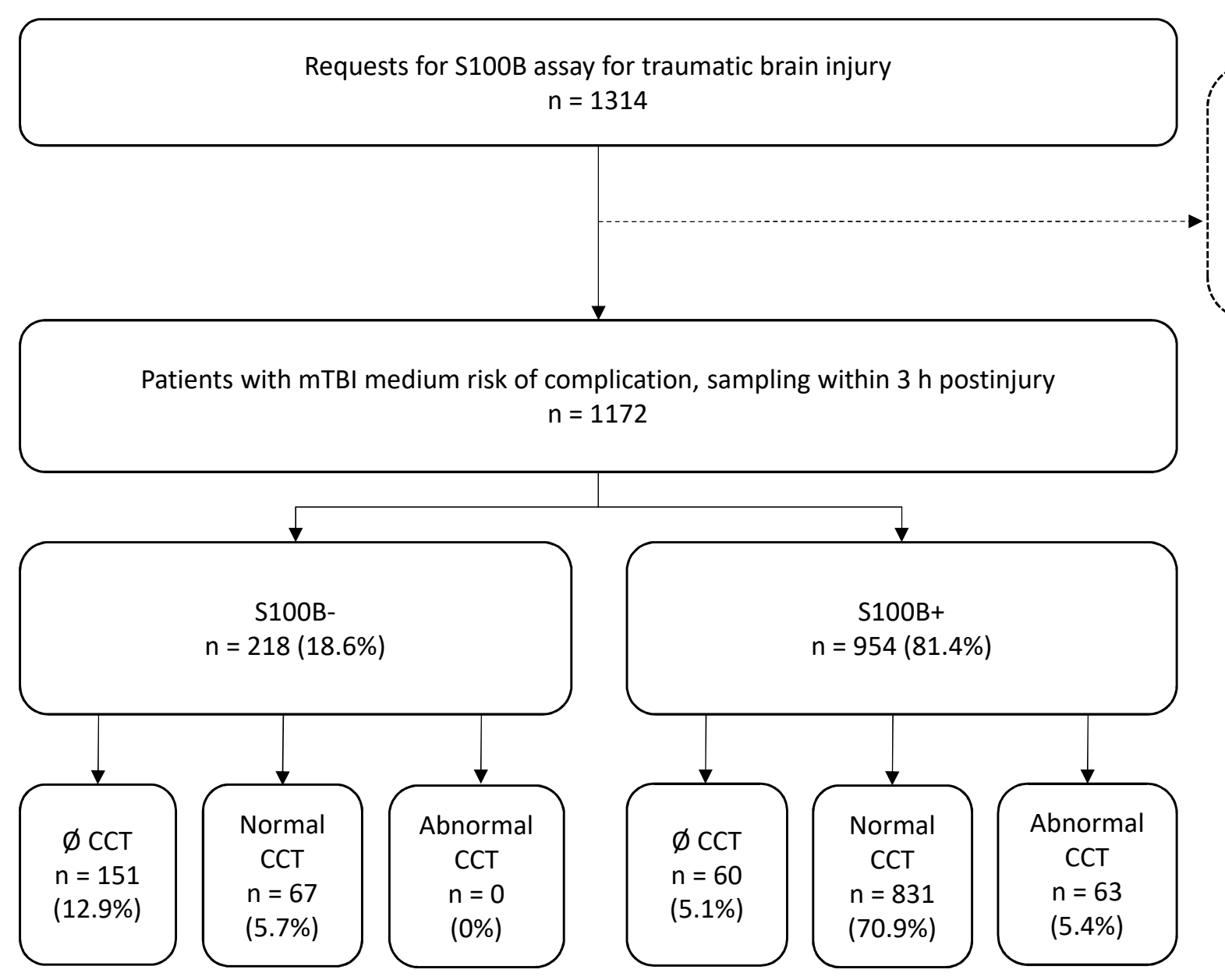

Excluded :

GCS $\leq 13(n=3)$

Time injury-S100B sampling $>3$ h or not communicated $(n=74)$

Patient with high risk of complication of $\mathrm{mTBI}(n=56)$

Patient with low risk of complication of $\operatorname{MTBI}(n=8)$

Information sheet uncompleted or absent $(n=1)$ 